\title{
Intensive grazing management systems for deer
}

G. STEVEN

Fairview, RD 2, Timan

coonoor@xtra,co.nz

\section{Introduction}

Vanaging pastures for maxinum production on a deer tot m can be challenging. Pasture growth is often not tell matched to animal demand and both hinds and stags nust be set stocked at certain times of the year. A piolferation of mobs restricts the farmers' ability to stablish proper grazing rotations. The making and feeding of supplements is a feature of many deer trining systems.

Common grazing management practice is to semi-set stock. Set stocking or slow rotations around a few iadocks lead to erosion, as fence lines and waterways suffer from constant wear and loss of vegetation. Electric fence use tends to be confined to allocating feed crops or strip grazing annual ryegrasses without back fences:

Feed pads are becoming a more common practise to vold the problems of winter pasture damage. Problems of nutrient transfer to the pads from the paddocks and the subsequent runoff from those pads result.

There used to be a profitability comfort zone with deer farming. Deer farmers have been complacent due to this Siperior profitability whilst sheep and beef farmers have been getting smarter by necessity. Twelve months ago ve sat down and re-assessed the role of deer on our farm. Two key issues became apparent. Firsty we had to reduce the amount of erosion they were causing and secondly we had to focus on growing and utilising grass inore efficiently;

Solving these problems presents something of a quanday. On one hand we need more and smaller paddocks, thus more fences. On the other hand we want tess fences. Fewer fences cquals less erosion. The solution seemed to be large permanertily fenced blocks subdivided with electric fencing that could be noved before erosion problems occurred. These fences needed to be laid out in a fashion which still enabled tasks such as fertiliser spreading, nowing, spraying etc to be done efficiently. Harry Weir, the developer of beef Technograzing and spider fencing, has provided the technology and hardware to make this possible.

This paper describes the progress we lave made to date asing electric subdivision for intensive rotational grazing of deer.
Canterbury since 1976. We currently farm 380 red hinds and 500 velveting stags and finish 130 home bred Wapiti $x$ weaners. We also run 450 ewes, 110 Friesian bulls and grow a variable area of cash crop. The $240 \mathrm{ha}$ dryland property is now mostly deer fenced. The contour is gently rolling clay downs $100 \mathrm{~m}$ above sea level with a $550 \mathrm{~mm}$ rainfall. The provision of shelter has always been a priority and is definitely a requirement under intensive grazing.

Erosion of fence lines and gullies by deer is an on going problem that really only becomes apparent when you start carting soil to repair it. As an example, $250 \mathrm{t}$ of soil was used to repair one $200 \mathrm{~m}$ fence line recently. This was the prine reason for trying to develop an intensive rotational grazing system. Secondary to this was a desire to grow more grass and spend less time feeding supplements.

Two dairy farmer maxims I find particularly relevant to this second aim are:

- Grass grows grass

and

- You can do anything to grass as long as it is only for 24 hours.

\section{Feeding hinds in winter}

First attenpts were made during the 2001 winter when feed was very short after another drought. Three hundred and twenty mixed age hinds were given 0.4 ha per day of cocksfoot (front and back fenced) with barley straw and sone grain occasionally. They very quickly learnt to run over the pinned down electric fence (live) onto their new block. Four hinds were removed from the mob for being repeat escapees.

The hinds stayed on this sort of regime until late Oetober. One hind died and four were taken out as dry in November, which had been pregnant in June. There were no out-breaks of Johnnes disease, MCF, internal parasites or any other diseases with the close confinement.

This winter the maiden hinds were also included in the mob of 400 . After the stags were withdrawn the various hind mobs were combined on a 5 ha paddock and given a week to establish their social order; This provided a settled single lerd to work with during the winter. Hinds were shifted daily in the late afternoon onto a 0.4 ha block and received silage on that block the following morning. Despite having no teeth the oldest hinds 
maintained or gained weight. The maiden hinds lost a lot of hair and about one condition score though none died or were removed from the mob. Scanning in late September resulted in four dries out of 108 maidens mated, a result we were very happy with. This would indicate that foetal loss dive to hierarchal stress is probably not an issue in deer.

Next year we intend to delay weaning until September and run all the hinds, fawns and maiden hinds in one mob. Hopefully the savings in time will offset the possibly delayed conception and inefficiencies of not being able to allocate the best feed to the weaners. We trialed this this year with the first calving hinds and achieved $100 \%$ conception, though the conception date is still to become apparent.

There was absolutely no weaning stress when it was eventually done. An added advantage would be the ability to shift a large portion of the deer stock units to a temporary feed pad during extended spells of wet weather.

Experiences to date suggest that the maximum stocking density is approximately $1000 / \mathrm{ha}$. This type of management maximises pasture quality through reducing dead material and increasing clover content, especially in the early spring. Deer graze very uniformly and not quite to the same level as sheep. Post grazing residuals are probably around $600 \mathrm{kgDM} / \mathrm{ha}$ yersus $400 \mathrm{kgDM} / \mathrm{ha}$ for ewes. This makes for significantly faster regrowth of the grazed pastures. The high stock density is also very effective at killing slugs and desiccating their eggs prior to dircet drilling.

The benefits of having an even spread of fertility across the paddock are, I believe, under estimated, and a major advantage of the system. Like fence line erosion, fertility transfer is an insidious and ongoing process that is too zasily ignored.

\section{Feeding lactating hinds and weaners}

A 14 ha block was direct drilled in red clover $(4 \mathrm{~kg} / \mathrm{ha}$ ) and chicory $(2 \mathrm{~kg} / \mathrm{ha})$ in spring 2001 . This was then fenced into 6 lanes $(65 \mathrm{~m}$ wide) using four $1,25 \mathrm{~mm}$ high tensile wires and $1.5 \mathrm{~m}$ fibreglass standards. Water lines were installed in every second fence line. Cross fences were erected to create eighteen 0.8 ha blocks. One hundred hinds and their fawns were grazed on the padioek from mid January being shifted daily, Another 100 hinds and their fawns were added in February.

Heavy rainfall during lanuary delayed the start, and combined with a new sowing meant that the feed offered was too long. Despite using different sowing dates the weather added to the problems of getting a rotation established. The conditions meant that the utilisation of the feed offered was only approximately $50 \%$. To get higher utilisation gave an unacceptable level of fence pacing. The chicory/red clover pasture was easily trampled and the damage reduced the palatability and therefore the utilisation.

Approximately 200 fawns were weaned back onto this block in late February. There were a continual number of fence breakers that became uncontrollable and so the group were removed. They have since been re-disciplined following the purchase of a new energiser. A powerful and reliable mains system is absolutely essential.

This spring grazing commenced on the block on 15 September with 160 wapiti and Hungarian cross weaners. Block size was increased to 1.2 ha and shifts every second day. (24 day rotation). Utilisation has been good with the dry weather and weight gains over the first two weeks appear to have been $400 \mathrm{~g} /$ day. There has been less pacing with the larger block size. When the deer are slaughtered at the end of October a high quality worm free pasture will be available to rapidly finish lambs before hinds and fawns start again in mid January I believe there are big productivity gains to be made by alternating species of stock and so reducing parasite burdens.

\section{Soil Damage}

This type of grazing system really highlights liow the contentedness of deer changes with different feding environments and weather. A wet night by the road with no shelter will mean a big mess. Away from the road on a sunny facing paddock and in dry frosty weather non contented animals would be hard to find. Shelter 1 . essential in wet windy weatler to avoid major fence pacing episodes. Sheltered blocks are saved for these conditions. From an animal welfare viewpoint this makes good sense.

Fences are destgned with shifting anntally in mind to avoid continual wear on a single fence line. Clips on the ends of the lane fences mean they can easily be pushed sideways several meters.

The deer still try to wallow if there is running or standing water present. These areas are either fenced o it or grazed when dry. Any leaks in the watering systen are quickly exploited, and need to be fixed immediately Wallowing damage is a lot less with daily shifting tari longer term grazing.

\section{Fencing and Labour}

Making the electric foncing system efficient is vial Kiwitech International, the developers of bef Techio grazing systems, were approached for ideas on adapting their system for deer. Their products and innovathe thinking have been a big help. How many of us ise electric fence standards that serve as wonderful earthes soon as a wire is knocked out of a clip? These are chtap 
fitrabsolutely worthless.

Kivitechs $1.25 \mathrm{~mm}$ high tensile wire has been used 10. he lane fences with tensioning springs at each end. It 4 possible to wind this wire on a spool, making a cheap 7id very durable temporary fence. With further 6evelopment $X$ hope that a four wire high tensile fence in be erected or dismantled with one pass on a four17eeler. Deer seem to respect the HT wire more than Volywire, possibly because of its better conductivity, or aecause it is harder to see. We have thrown most of our 10l tape away with the mefal standards, finding it a noor conductor and no good in the wind.

Hinds seemed to be quick to take advantage if the tottom wire is more than $20 \mathrm{~cm}$ off the ground. Three or ben two wires may suffice with good training. Gurenty the milti wire requiremients of the system trean that the running of smaller mobs in separate lanes ani t be readily achieved.

Iraining is critical and probably best achieved with a high specification fence at a young age. Inclusion of an carth wire in this fence could be advantageous. Weaning ndoors with a week or so quictening and disciplining to telectics is something we would like to try.

\section{Water Systems}

Water use to date has been minimal, though we have yet to go through a dry summer with lactating hinds. Kiwitechs technology makes for efficient temporary watering systems. Alkathene pipe can be towed around with a four-wheeler as in $\mathrm{K}$ - line irtigation, so not every paddock has to have fixed water lines.

\section{Conclusions}

There is no doubt other deer farmers are adopting similar grazing systems, or have already tried to. There is still much to leam and some technological advances to make. The biggest draw back with any intensive grazing system is the commitment to be constantly shifting stock. No matter how fast it is someone still has to go out and do it. This is complicated with deer in that you need to have one ear on the weather forecast so that shifts to sheiter can be made in advance. We have achieved the aims of reducing erosion and growing more grass though don't have many hard facts yet to support these elaims. In another welve months time we will be in a better position to comment on the practicality of these systems to mainstream deer farmers. 